\begin{tabular}{cc} 
Sharif University of Technology \\
Scientia Iranica \\
SCIENTIA & Transactions F: Nanotechnology \\
I RAN I CA & http://scientiairanica.sharif.edu \\
\hline
\end{tabular}

\title{
Comparison of disparate solid volume fraction ratios of hybrid nanofluids flow over a permeable flat surface with aligned magnetic field and Marangoni convection
}

\author{
A.K. Abdul Hakeem ${ }^{\mathrm{a}, *}$, N. Indumathi ${ }^{\mathrm{a}}$, B. Ganga ${ }^{\mathrm{b}}$, and M.K. Nayak ${ }^{\mathrm{c}}$ \\ a. Department of Mathematics, Sri Ramakrishna Mission Vidyalaya College of Arts and Science, Coimbatore - 641 020, India. \\ b. Department of Mathematics, Providence College For Women, Coonoor - 643104, India. \\ c. Radhakrishna Institute of Technology and Engineering, Biju Patnaik University of Technology, Odisha, India.
}

Received 30 August 2018; received in revised form 2 November 2018; accepted 11 January 2020

\author{
KEYWORDS \\ Hybrid-nanofluids; \\ Aligned magnetic \\ field; \\ Marangoni convection; \\ Heat transfer; \\ Mass transfer.
}

\begin{abstract}
Over the past decade, the preparation, characterization, and modeling of nanofluids have been plentifully studied to improve the effects of heat transfer. Hence, to gratify the advancements, this paper focuses on heat transfer effects of three distinct hybrid nanoparticles $\left(\mathrm{Al}_{2} \mathrm{O}_{3}-\mathrm{SiO}_{2}, \mathrm{Al}_{2} \mathrm{O}_{3}-\mathrm{TiO}_{2}, \mathrm{TiO}_{2}-\mathrm{SiO}_{2}\right)$ with a base fluid (water). Therefore, this work numerically investigated the effect over a permeable flat surface with an aligned magnetic field in the presence of suction, injection, or impermeability together with the Marangoni convection of different hybrid nanofluids. The present results were validated in accordance with previous experimental and numerical results. The effects of solid volume fraction of hybrid nanoparticles, angle of inclination, magnetic parameter, and wall mass transfer parameter were studied and shown through graphs together with the surface velocity. In addition, the rate of heat transfer was presented in the tabular form. It was found that the rate of heat transfer increased as the wall mass transfer increased, considering the opposite effect of the rise of magnetic parameter. Among the three hybrid nanofluids, $\mathrm{Al}_{2} \mathrm{O}_{3}-\mathrm{SiO}_{2}$ /water hybrid nanofluid showed a higher surface velocity, $\mathrm{Al}_{2} \mathrm{O}_{3}-$ $\mathrm{TiO}_{2}$ /water hybrid nanofluid had higher temperature profile, and $\mathrm{TiO}_{2}-\mathrm{SiO}_{2}$ / water hybrid nanofluid exhibited a higher heat transfer rate.
\end{abstract}

(C) 2020 Sharif University of Technology. All rights reserved.

\section{Introduction}

Compared to liquids, solids are characterized by high thermal conductivity. Two decades ago, to advance the thermal properties of conventional fluids, the low volume fraction of solid nanoparticles was dispersed in base fluid (water, alcohol, or oil). This fluid was first termed as nanofluid by Choi [1] in 1995. Meanwhile,

\footnotetext{
*. Corresponding author. Tel.: +919442401998 E-mail address: abdulhakeem6@gmail.com (A.K. Abdul Hakeem)
}

doi: $10.24200 /$ SCI.2020.51681.2312 the preparation, characterization, and modeling of nanofluids have been considered by many researchers. Simultaneously, many investigators have studied the heat transfer effects of nanofluids. In addition, through experimental and numerical investigations, it has been found that the heat transfer rate increases by a notable percentage because of the nanofluid, which is influenced by concentration size, shape, and some other properties of nanoparticles.

However, these results do not gratify the engineering advancements. To satisfy the constraints and produce an innovative idea in this respect, hybrid nanofluid is considered. A combination of two or more nanoparticles into base fluid is known as hybrid 
nanofluid. When materials of these combined nanoparticles are selected appropriately, they must strengthen the positive aspects of each other.

Afrand et al. [2] showed that the hybrid-nanofluid $\mathrm{SiO}_{2}-\mathrm{MWCNT} / \mathrm{AE} 40$ reached the greatest viscosity increment to $37.4 \%$ as a lubricant and as a coolant at a solid volume fraction of $1 \%$ and at a temperature of $60^{\circ} \mathrm{C}[3]$. By considering an enhancement in the volume concentration of hybrid nanofluid $\left(\mathrm{Al}_{2} \mathrm{O}_{3}-\mathrm{CuO} /\right.$ water $)$, an increment in the incline angle and a hike in heat input can reduce the thermal resistance of a circular heat pipe. The experimental data [4] matched well with the estimated empirical correlations of the Nusselt number and friction factor of $\mathrm{CNT}-\mathrm{Fe}_{3} \mathrm{O}_{4} /$ water hybrid nanofluid. In a review by Azwadi et al. [5] and Sarkar et al. [6], the affecting factors in hybrid nanofluid performance were scrutinized in detail. Momin [7] synthesized $\mathrm{Al}_{2} \mathrm{O}_{3}-\mathrm{Cu}$ nanocomposite powder by the hydrogen reduction technique and prepared a volume concentration of $0.1 \%$ in deionized water.

Moldoveanu et al. [8] measured the viscosity of $\mathrm{Al}_{2} \mathrm{O}_{3}-\mathrm{TiO}_{2}$ hybrid. The relative viscosity with volume fraction is connected by the regression analysis of hybrid nanofluid, and both nanofluids are very well in agreement with experimental data. Moldoveanu et al. [9] prepared stabilized $\mathrm{Al}_{2} \mathrm{O}_{3}, \mathrm{SiO}_{2}$ nanofluids and their hybrids. Hybrid nanofluid viscosity variations with temperature were measured and studied. It was found that an increase in temperature reduced the viscosity of hybrid nanofluid. Abdul Hamid et al. [10] observed different ratios of $1 \%$ volume concentration in $\mathrm{TiO}_{2}-\mathrm{SiO}_{2}$ hybrid with the base fluid water and ethylene glycol mixture (60:40). Their conclusion demonstrated that the best mixture ratios for $\mathrm{TiO}_{2}-$ $\mathrm{SiO}_{2}$ to enhance the dynamic viscosity and thermal conductivity were 40:60 and 80:20.

According to Sahoo et al. [11], when hybrid nanofluids were used as a radiator coolant, $\mathrm{Al}_{2} \mathrm{O}_{3}$ $+\mathrm{Ag} /$ water-based hybrid nanofluid showed greater efficiency in numerical terms. In the presence of the magnetic field, Anjali Devi and Surya Uma Devi [12] concluded that hybrid nanofluid $\left(\mathrm{Cu}-\mathrm{Al}_{2} \mathrm{O}_{3} /\right.$ water $)$ showed a higher heat transfer rate. A new 3D model was employed by Hayat and Nadeem [13] and led to a conclusion that hybrid nanofluid ( $\mathrm{Ag}-\mathrm{CuO} /$ water) showed a higher heat transfer rate than nanofluid ( $\mathrm{CuO} /$ water). Azwadi et al. [14] argued that the thermal physiognomies of hybrid nanofluids were more sophisticated than nanofluids. Recently, Gorla et al. [15] studied numerically $\mathrm{Al}_{2} \mathrm{O}_{3}+\mathrm{CuO} /$ water-based hybrid nanofluids with heat source/sink effects.

Kuznetsov and Nield [16] investigated a vertical plate and a natural convective boundary layer flow of nanofluid. Numerically, Abderrahim et al. [17] examined natural convective $\mathrm{Cu}$-water single-and twophase nanofluid models with thermal radiation effects.
Sheikoleslami et al. [18] studied the free convection heat transfer of nanofluid between a hot inner sinusoidal and a cold outer circular cylinder. Abdul Hakeem et al. [19] concluded that the reduced Nusselt number of metallic nanofluids was lower than that of nonmetallic nanofluids in stretching and shrinking sheets with natural convection. In the presence of an aligned magnetic field, Hussain et al. [20] investigated the natural convection flow of magneto-nanofluid past a vertical infinite ramped temperature plate. They concluded that the nanofluid velocity and temperature were higher for an isothermal plate than those for the ramped temperature plate. MHD flow of metallic and nonmetallic nanoparticle-based nanofluids over a stretching/shrinking surface was studied by Abdul Hakeem et al. [21], and it was concluded that the heat transfer rate was higher for silver-water nanofluid and lower for Aluminium-water nanofluid in the cases of upper and lower branch solutions of the shrinking sheet. Extensive attention has been given to numerical and analytical studies of the permeable stretching sheet in the presence of heat generation and absorption [22-26]. Abdul Hakeem et al. [27] analyzed that the entropy generation was lower for $\mathrm{Al}_{2} \mathrm{O}_{3}$ and $\mathrm{TiO}_{2}$ nanoparticles and higher for $\mathrm{Cu}$, Ag nanoparticles with base fluid as water in the presence of a magnetic field. Eid and Makinde [28] discussed magneto nanofluid flow past a convectively heated stretching sheet surrounded by the porous medium. Recently, Hayat et al. [29] studied the non-Newtonian material radial magnetic field effect in a curved channel with Soret and Dufour effects.

Marangoni convection is induced by the variations of the surface tension gradients along the liquidliquid or liquid-gas interfaces. The boundary layer flow of Marangoni convection has received significant deliberation and attention due to its wide range of applications in crystal growth melts. Mudhaf and Chamka [30] presented a similarity solution to MHD thermosolutal Marangoni convection over a flat surface. In the presence of the inclined magnetic field, Hayat et al. [31] investigated the Marangoni mixed convection flow for Casson fluid over a permeable surface. To the best knowledge of the authors, Marangoni convection with an aligned magnetic field on hybrid nanofluid has not yet been done. The relationship among Marangoni number, Reynolds number, and Prandtl number was derived by Christopher et al. [32].

The study of hybrid nanofluid is still in infancy. Oxide nanoparticles are the preferred nanoparticles because of their resistance to oxidation along with fewer particle setting problems; in addition, their density is lower than the metal density. Hence, by considering the advantages of oxide nanoparticles and the experimental studies in [8-10], three different oxide hybrid nanofluids $\left(\mathrm{Al}_{2} \mathrm{O}_{3}-\mathrm{SiO}_{2}, \mathrm{Al}_{2} \mathrm{O}_{3}-\mathrm{TiO}_{2}, \mathrm{TiO}_{2}-\mathrm{SiO}_{2} /\right.$ water $)$ with an aligned magnetic field past a permeable flat surface 
with Marangoni convection is investigated numerically in the present work.

\section{Mathematical formulation}

This study considers a steady, two-dimensional, incompressible, laminar and Marangoni boundary layer flow of water-based hybrid nanofluids containing different types of hybrid nanoparticles $\mathrm{Al}_{2} \mathrm{O}_{3}-\mathrm{SiO}_{2}, \mathrm{Al}_{2} \mathrm{O}_{3}-$ $\mathrm{TiO}_{2}, \mathrm{TiO}_{2}-\mathrm{SiO}_{2}$, past a permeable surface with an aligned magnetic field. The hybrid nanoparticles and the base fluid are assumed to be in thermal equilibrium, and no slip occurs between them. The surface tension, $\sigma$, is considered to vary linearly with temperature as follows [33]:

$$
\sigma=\sigma_{*}\left(1-\gamma\left(T-T_{*}\right)\right),
$$

where $\sigma_{*}$ and $T_{*}$ are the surface tension and temperature at the slit, respectively, and it is considered that $T_{*} \equiv T_{\infty}$. Along with temperature, for most liquids, the surface tension $(\sigma)$ declines. That is, $\gamma>0$ for fluid property. The thermophysical properties of nanoparticles are given in Table 1.

Moreover, this study assumes the Cartesian coordinate system $(x, y)$, where $x$ is the coordinate measured along the plate and $y$ is the coordinate measured normal to it, where the flow takes place at $y \geq 0$. It is further considered that the temperature of the surface is $T_{w}(x)$. An aligned magnetic field with an acute angle $\alpha$ spreads on the flow, as shown in Figure 1.

Under the above considerations, the governing equations are given by:

$$
\begin{aligned}
& \frac{\partial u}{\partial x}+\frac{\partial v}{\partial y}=0, \\
& u \frac{\partial u}{\partial x}+v \frac{\partial u}{\partial y}=\frac{\mu_{h n f}}{\rho_{h n f}} \frac{\partial^{2} u}{\partial y^{2}}-\frac{\delta B_{0}^{2} u}{\rho_{h n f}} \sin ^{2} \alpha, \\
& u \frac{\partial T}{\partial x}+v \frac{\partial T}{\partial y}=\alpha_{h n f} \frac{\partial^{2} T}{\partial y^{2}} .
\end{aligned}
$$

subject to the boundary conditions:

$$
\begin{aligned}
& v=v_{w}, \quad T=T_{\infty}+A x^{2}, \\
& \mu_{h n f} \frac{\partial u}{\partial y}=\frac{\partial \sigma}{\partial T} \frac{\partial T}{\partial x} \quad \text { at } \quad y=0, \\
& u=0, \quad T=T_{\infty} \quad \text { as } \quad y \rightarrow \infty,
\end{aligned}
$$

Table 1. Thermophysical properties of nanoparticles and base fluid.

\begin{tabular}{lcccc}
\hline \multicolumn{1}{c}{ Property } & $\mathbf{A l}_{\mathbf{2}} \mathbf{O}_{\mathbf{3}}$ & $\mathbf{S i O}_{\mathbf{2}}$ & $\mathbf{T i O}_{\mathbf{2}}$ & Pure water \\
\hline$C_{p}(\mathrm{~J} / \mathrm{kgK})$ & 765 & 703 & 692 & 4181 \\
$\rho\left(\mathrm{kg} / \mathrm{m}^{2}\right)$ & 3970 & 2200 & 4175 & 996.5 \\
$K(\mathrm{~W} / \mathrm{mK})$ & 40 & 1.2 & 8.4 & 0.613 \\
\hline
\end{tabular}

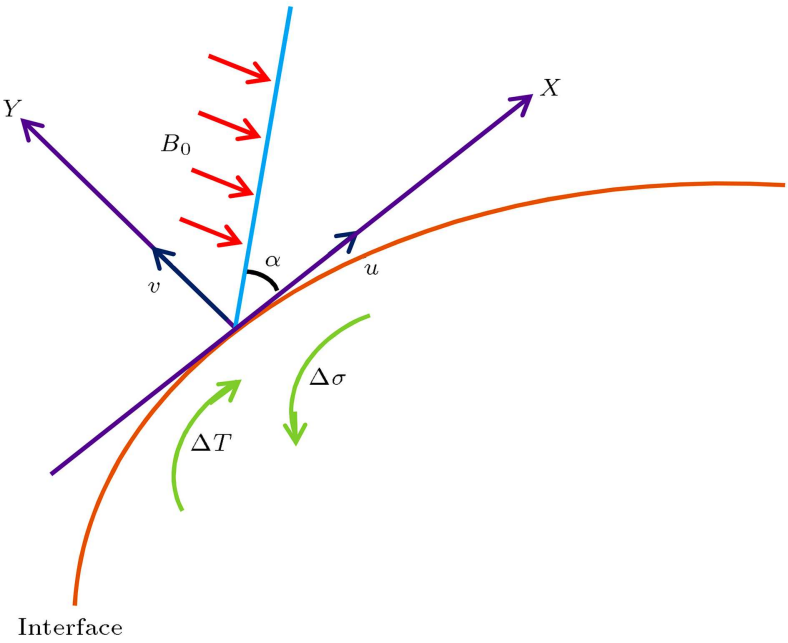

Figure 1. Physical configuration with interface condition and coordinate system.

where $u$ and $v$ are velocity components along the $x$ and $y$ axes, respectively. $T$ is the temperature of the hybrid nanofluid, $\mu_{h n f}$ is the effective viscosity of hybrid nanofluid, and $\rho_{h n f}$ is the effective density of the hybrid nanofluid. $\delta$ is the electrical conductivity. $B_{0}$ is the uniform magnetic field. $\alpha_{h n f}$ is the thermal diffusivity of the hybrid nanofluid, and $k_{h n f}$ is the effective thermal conductivity of hybrid nanofluid, as given by [12]:

$$
\begin{aligned}
\mu_{h n f} & =\frac{\mu_{f}}{\left(1-\phi_{1}\right)^{2.5}\left(1-\phi_{2}\right)^{2.5}}, \\
\rho_{h n f} & =\left\{\left(1-\phi_{2}\right)\left[\left(1-\phi_{1}\right) \rho_{f}+\phi_{1} \rho_{s_{1}}\right]\right\}+\phi_{2} \rho_{s_{2}}, \\
\alpha_{h n f} & =\frac{k_{h n f}}{\left(\rho C_{p}\right)_{h n f}}, \\
\frac{k_{h n f}}{k_{n f}} & =\frac{k_{s_{2}}+(n-1) k_{n f}-(n-1) \phi_{2}\left(k_{n f}-k_{s_{2}}\right)}{k_{s_{2}}+(n-1) k_{n f}+\phi_{2}\left(k_{n f}-k_{s_{2}}\right)}
\end{aligned}
$$

where:

$$
\frac{k_{n f}}{k_{f}}=\frac{k_{s_{1}}+(n-1) k_{f}-(n-1) \phi_{1}\left(k_{f}-k_{s_{1}}\right)}{k_{s_{1}}+(n-1) k_{f}+\phi_{1}\left(k_{f}-k_{s_{1}}\right)} .
$$

From Figure 2, the relative viscosity for $\mathrm{Al}_{2} \mathrm{O}_{3}-\mathrm{TiO}_{2}$ correlates with the experimental results of Moldoveanu et al. [8]; specifically, the hybrid nanofluid is plotted for different volume fractions such as $0.5 \% \quad \mathrm{Al}_{2} \mathrm{O}_{3}-$ $0.5 \% \quad \mathrm{TiO}_{2}, 0.5 \% \mathrm{Al}_{2} \mathrm{O}_{3}-1 \% \mathrm{TiO}_{2}$, and $0.5 \% \mathrm{Al}_{2} \mathrm{O}_{3}-$ $1.5 \% \mathrm{TiO}_{2}$, showing a viable correlation with the experimental results. Hence, the thermophysical properties (Eq. (7)) are adopted for the three cases of oxide hybrid nanofluids: $\mathrm{Al}_{2} \mathrm{O}_{3}-\mathrm{SiO}_{2}$ /water, $\mathrm{Al}_{2} \mathrm{O}_{3}-\mathrm{TiO}_{2}$ /water, and $\mathrm{TiO}_{2}-\mathrm{SiO}_{2} /$ water.

To get a similarity solution to Eqs. (2)-(4), the boundary conditions as in Eqs. (5) and (6) of the 


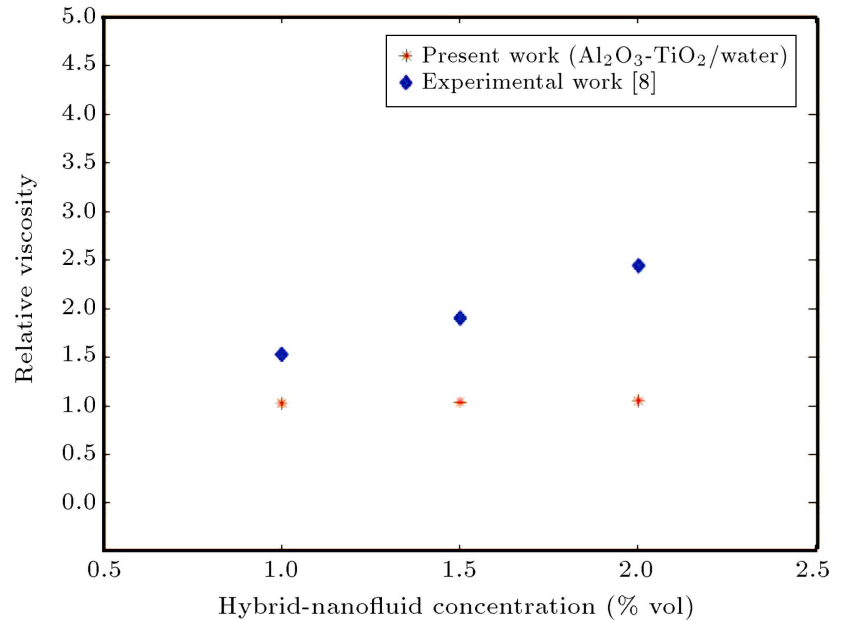

Figure 2. Relative viscosity comparison graph of $\mathrm{Al}_{2} \mathrm{O}_{3}-\mathrm{TiO}_{2}$ water hybrid nanofluid of current work and Moldoveanu et al. [8].

succeeding form are given by $[30,34,35]$ as follows:

$$
\psi(\eta)=\zeta_{2} x f, \quad \theta=\frac{T-T_{\infty}}{A x^{2}}, \quad \eta=\zeta_{1} y,
$$

where $u=\frac{\partial \psi}{\partial y}, v=-\frac{\partial \psi}{\partial x}$, and the stream function is $\psi$. Additionally, $A, \zeta_{1}$, and $\zeta_{2}$ are the constants given by the following:

$$
\begin{aligned}
& A=\frac{\Delta T}{L^{2}}, \quad \zeta_{1}=\left(\frac{\sigma_{*} \gamma A \rho_{f}}{\mu_{f}^{2}}\right)^{\frac{1}{3}}, \\
& \zeta_{2}=\left(\frac{\sigma_{*} \gamma A \mu_{f}}{\rho_{f}^{2}}\right)^{\frac{1}{3}},
\end{aligned}
$$

where $\Delta T$ is the constant characteristic temperature, and $L$ is the surface length. By substituting Eqs. (7) and (8) into Eqs. (3) and (4), the ordinary differential equations, as shown in Box I, are obtained. The boundary conditions are transformed as follows:

$$
\begin{aligned}
& f=f_{w}, \quad f^{\prime \prime}(0)=-2\left(1-\phi_{1}\right)^{2.5}\left(1-\phi_{2}\right)^{2.5}, \\
& \theta(0)=1,
\end{aligned}
$$

$$
f^{\prime}(\eta \rightarrow \infty)=0, \quad \theta(\eta \rightarrow \infty)=0,
$$

where $\operatorname{Pr}$ is the Prandtl number, $\phi_{1}$ is the solid volume fraction of $\mathrm{Al}_{2} \mathrm{O}_{3}$ in $\mathrm{Al}_{2} \mathrm{O}_{3}-\mathrm{SiO}_{2}$ /water and $\mathrm{Al}_{2} \mathrm{O}_{3}-\mathrm{TiO}_{2}$ /water hybrid nanofluids and that of $\mathrm{TiO}_{2}$ in $\mathrm{TiO}_{2}-\mathrm{SiO}_{2}$ /water hybrid nanofluid, and $\phi_{2}$ is the solid volume fraction of $\mathrm{SiO}_{2}$ in $\mathrm{Al}_{2} \mathrm{O}_{3}-\mathrm{SiO}_{2}$ /water and $\mathrm{TiO}_{2}-\mathrm{SiO}_{2}$ /water hybrid nanofluids and that of $\mathrm{TiO}_{2}$ in $\mathrm{Al}_{2} \mathrm{O}_{3}-\mathrm{TiO}_{2}$ /water hybrid nanofluid. $M$ is the magnetic parameter. $\alpha$ is the angle of inclination. $f_{w}$ is the wall mass transfer parameter $\left(f_{w}>0\right.$, suction parameter, $f_{w}=0$ impermeability, and $f_{w}<0$ injection (or) blowing parameter). Now, the surface velocity $u(x, 0)=u_{w}(x)$ can be investigated as follows:

$$
u_{w}(x)=\left(\frac{\left(\sigma_{*} \gamma A\right)^{2}}{\rho_{f} \mu_{f}}\right)^{1 / 3} x f^{\prime}(0) .
$$

Another important characteristic of the present investigation is the Nusselt number, which is given by:

$$
\mathrm{Nu}_{x}=-\frac{k_{h n f}}{k_{f}} \zeta_{1} x \theta^{\prime}(0) .
$$

The average Nusselt number depends on the average temperature difference between the temperature of the surface and the temperature far from the surface, as given by Arifin et al. [35]. Now, the average Nusselt number for hybrid nanofluids is calculated as follows:

$$
\mathrm{Nu}_{L}=-\frac{k_{h n f}}{k_{f}} \mathrm{Ma}_{L}^{1 / 3} \operatorname{Pr}^{1 / 3} \theta^{\prime}(0),
$$

where $\mathrm{Ma}_{L}$ is the Marangoni number based on $L$ and defined as follows:

$$
\mathrm{Ma}_{L}=\frac{\sigma_{*} A L^{2}}{\mu_{f} \alpha_{f}}=\frac{\sigma_{*} \Delta T L}{\mu_{f} \alpha_{f}} .
$$

The Reynolds number defined in terms of the surface velocity is then related to the Marangoni number as follows:

$$
\operatorname{Re}_{L}=\frac{u(x, 0) L}{\nu_{f}}=f^{\prime}(0) \mathrm{Ma}_{L}^{2 / 3} \operatorname{Pr}^{-2 / 3} .
$$

$$
\begin{aligned}
& {\left[\frac{1}{\left(1-\phi_{1}\right)^{2.5}\left(1-\phi_{2}\right)^{2.5}\left(\left(1-\phi_{2}\right)\left[\left(1-\phi_{1}\right)+\phi_{1} \rho_{s_{1}} / \rho_{f}\right]+\phi_{2} \rho_{s_{2}} / \rho_{f}\right)}\right] f^{\prime \prime \prime}+f f^{\prime \prime}-f^{\prime 2}} \\
& \quad-\left[\frac{M \sin ^{2} \alpha}{\left(\left(1-\phi_{2}\right)\left[\left(1-\phi_{1}\right)+\phi_{1} \rho_{s_{1}} / \rho_{f}\right]+\phi_{2} \rho_{s_{2}} / \rho_{f}\right)}\right] f^{\prime}=0, \\
& \frac{1}{\operatorname{Pr}}\left[\frac{1}{\left(1-\phi_{2}\right)\left(1-\phi_{1}\right)+\phi_{1}\left(\rho C_{P}\right)_{s_{1}} /\left(\rho C_{P}\right)_{f}+\phi_{2}\left(\rho C_{p}\right)_{s_{2}} /\left(\rho C_{p}\right)_{f}}\right] \frac{k_{h n f}}{k_{f}} \theta^{\prime \prime}-2 f^{\prime} \theta+f \theta^{\prime}=0,
\end{aligned}
$$


Table 2. Values of $f^{\prime \prime}(0)$ for various values of solid volume fraction.

\begin{tabular}{ccccc}
\hline$\phi_{\mathbf{1}}$ & $\boldsymbol{\phi}_{\mathbf{2}}$ & Sastry et al. [34] & Hamid and Arifin [36] & Present work \\
\hline 0 & 0 & -2 & -2 & -2 \\
0.1 & 0 & -1.53686694 & -1.53686694 & -1.53686694 \\
0.2 & 0 & -1.14486680 & -1.14486680 & -1.14486680 \\
\hline
\end{tabular}

\section{Numerical solution}

The non-linear dimensionless ordinary differential Eqs. (10) and (11) subjected to the boundary conditions Eqs. (12) and (13) are solved numerically using the fourth-order R-K method with the shooting technique at different values of governing parameters. The boundary value problem is initially transformed into an initial value problem and, then, the initial value problem is solved numerically. The step size of $\Delta \eta=0.01$ is used to obtain the numerical solution with $\eta_{\max }=20$, where $\max \eta_{\max }$ is the finite value of the similarity variable $\eta$ for the far-field boundary conditions. The convergence is assured by taking error $10^{-6}$ in all cases.

Numerical solutions are obtained and given by graphs and tables.

\section{Results and discussion}

The Marangoni convection boundary layer flow with an aligned magnetic field of three distinct hybrid nanofluids, namely, $\mathrm{Al}_{2} \mathrm{O}_{3}-\mathrm{SiO}_{2}$ /water, $\mathrm{Al}_{2} \mathrm{O}_{3}-\mathrm{TiO}_{2} /$ water, and $\mathrm{TiO}_{2}-\mathrm{SiO}_{2} /$ water with heat and wall mass transfer effects past a flat surface is discussed in the cases of suction, impermeability, and injection (blowing). The transformed ordinary differential equation with the boundary conditions is solved using the fourthorder R-K method by the shooting technique. In the present study, it is conversed in the cases of suction $\left(f_{w}>0\right.$ and is dosed as $\left.f_{w}=0.5\right)$, impermeability $\left(f_{w}=0\right)$, and injection $\left(f_{w}<0\right.$ and is dosed as $\left.f_{w}=-0.5\right)$ together with the magnetic parameter $(M=3)$, angle of inclination $(\alpha=\pi / 3)$, and base fluid water Prandtl number $(\operatorname{Pr}=6.2)$. Tables and several plots have been drawn to represent the effect of the parameters, mainly solid volume fraction, angle of inclination, magnetic parameter, and wall mass transfer $\left(f_{w}\right)$. Specifically, the velocity and temperature profiles for $\mathrm{Al}_{2} \mathrm{O}_{3}-\mathrm{SiO}_{2}$ /water, $\mathrm{Al}_{2} \mathrm{O}_{3}-\mathrm{TiO}_{2} /$ water, and $\mathrm{TiO}_{2}-$ $\mathrm{SiO}_{2} /$ water have been plotted with black color for suction, green color for impermeability, and red color for injection. In this work, at first, the nanoparticle volume fraction $\phi_{1}$ of $\mathrm{Al}_{2} \mathrm{O}_{3}$ in $\mathrm{Al}_{2} \mathrm{O}_{3}-\mathrm{SiO}_{2}$ /water and $\mathrm{Al}_{2} \mathrm{O}_{3}-\mathrm{TiO}_{2} /$ water and $\mathrm{TiO}_{2}$ in $\mathrm{TiO}_{2}-\mathrm{SiO}_{2} /$ water is fixed at 2.5\%; simultaneously, the same in $\mathrm{SiO}_{2}$ in $\mathrm{Al}_{2} \mathrm{O}_{3}-\mathrm{SiO}_{2} /$ water and $\mathrm{TiO}_{2}-\mathrm{SiO}_{2} /$ water and $\mathrm{TiO}_{2}$ in $\mathrm{Al}_{2} \mathrm{O}_{3}-\mathrm{TiO}_{2} /$ water is fixed at $0.5 \%$. To validate the system used, a comparison of the current results obtained by Sastry et al. [34] and Hamid and Arifin [36] is shown in Table 2 .

The effect of solid volume fraction $\phi_{1}$ of $\mathrm{Al}_{2} \mathrm{O}_{3}$ in $\mathrm{Al}_{2} \mathrm{O}_{3}-\mathrm{SiO}_{2}$ /water and $\mathrm{Al}_{2} \mathrm{O}_{3}-\mathrm{TiO}_{2}$ /water is shown in Figure 3(a) and (b), respectively. Figure 3(c) shows $\mathrm{TiO}_{2}$ in $\mathrm{TiO}_{2}-\mathrm{SiO}_{2} /$ water hybrid nanofluids in three cases of wall mass transfer parameter $\left(f_{w}\right)$ (injection, impermeability, and suction). While the values of $\phi_{1}$ increase, the velocity profile declines for all of the three hybrid nanofluids. In physical terms, the inclusion of hybrid nanoparticles in the base fluid induces resistance that occurs because of their relatively higher density than the base fluid. Moreover, while increasing the wall mass transfer parameter $\left(f_{w}\right), \mathrm{Al}_{2} \mathrm{O}_{3}-\mathrm{SiO}_{2} /$ water, $\mathrm{Al}_{2} \mathrm{O}_{3}-\mathrm{TiO}_{2} /$ water, and $\mathrm{TiO}_{2}-\mathrm{SiO}_{2}$ /water hybrid nanofluids are retarded in a similar manner. This is because an increase in wall mass transfer parameter has the propensity to strength the fluid into an unoccupied space that creates variations in the boundary layer. Hence, the velocity is decelerated when the wall mass transfer parameter increases for all of the three hybrid nanofluids.

Figure 4(a)-(c) represents the dimensionless velocity for the various values of solid volume fractions $\phi_{2}$ for $\mathrm{SiO}_{2}$ in two hybrid nanofluids of $\mathrm{Al}_{2} \mathrm{O}_{3}-\mathrm{SiO}_{2} /$ water (Figure 4(a)) $\mathrm{TiO}_{2}-\mathrm{SiO}_{2} /$ water (Figure 4(c)) and for $\mathrm{TiO}_{2}$ in $\mathrm{Al}_{2} \mathrm{O}_{3}-\mathrm{TiO}_{2} /$ water (Figure 4(b)). While the solid volume fraction $\phi_{2}$ increases from 0.005 to 0.02 and 0.04 , the velocity profile is retarded for $\mathrm{Al}_{2} \mathrm{O}_{3}-\mathrm{SiO}_{2}$ /water, $\mathrm{Al}_{2} \mathrm{O}_{3}-\mathrm{TiO}_{2}$ /water, and $\mathrm{TiO}_{2}-$ $\mathrm{SiO}_{2} /$ water hybrid nanofluids in the three cases of wall mass transfer parameter $\left(f_{w}\right)$, namely injection, impermeability, and suction cases. The velocity profile slightly increases after $\eta=1$ only for $\mathrm{Al}_{2} \mathrm{O}_{3}-$ $\mathrm{SiO}_{2} /$ water hybrid nanofluid (Figure 4(a)) for the varying values of wall mass transfer. This is due to the fact that a hike in the nanoparticle volume fraction increases the energy exchange rates; hence, the movements of particles become irregular and random.

The velocity distribution for various equal solid volume fractions of hybrid nanoparticles $\phi_{1}=\phi_{2}$ for $\mathrm{Al}_{2} \mathrm{O}_{3}-\mathrm{SiO}_{2} /$ water (Figure 5(a)), $\mathrm{Al}_{2} \mathrm{O}_{3}-\mathrm{TiO}_{2} /$ water (Figure 5(b)), and $\mathrm{TiO}_{2}-\mathrm{SiO}_{2} /$ water (Figure 5(c)) is shown in Figure 5 . While the values of solid volume fractions of both nanoparticles of hybrid nanofluid increase, the velocity profile diminishes. The decline in distribution with the solid volume fractions $\phi_{1}$ and $\phi_{2}$ 


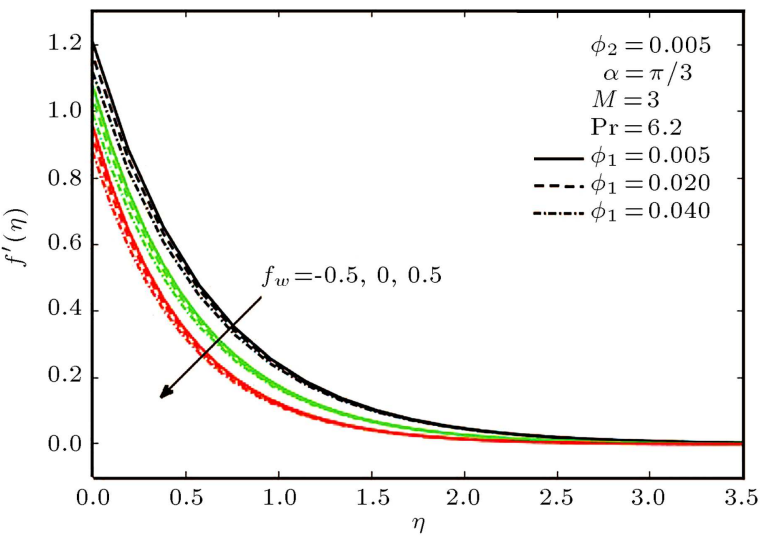

(a) $\mathrm{Al}_{2} \mathrm{O}_{3}-\mathrm{SiO}_{2} /$ water

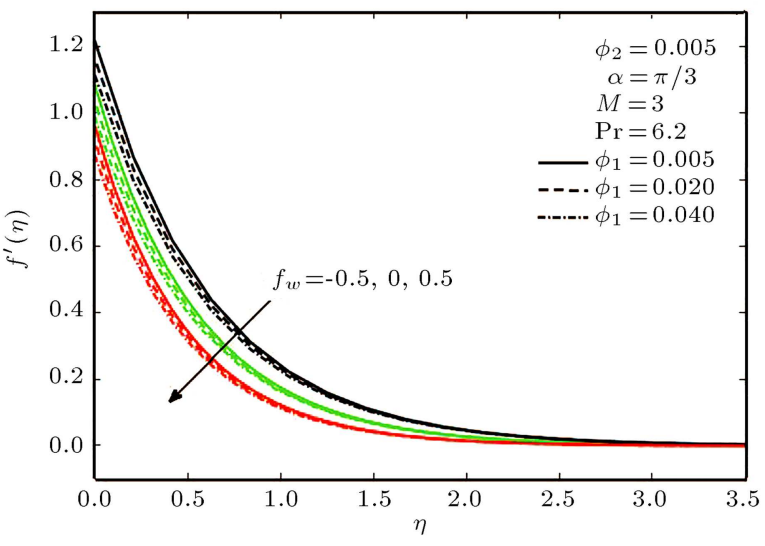

(b) $\mathrm{Al}_{2} \mathrm{O}_{3}-\mathrm{TiO}_{2} /$ water

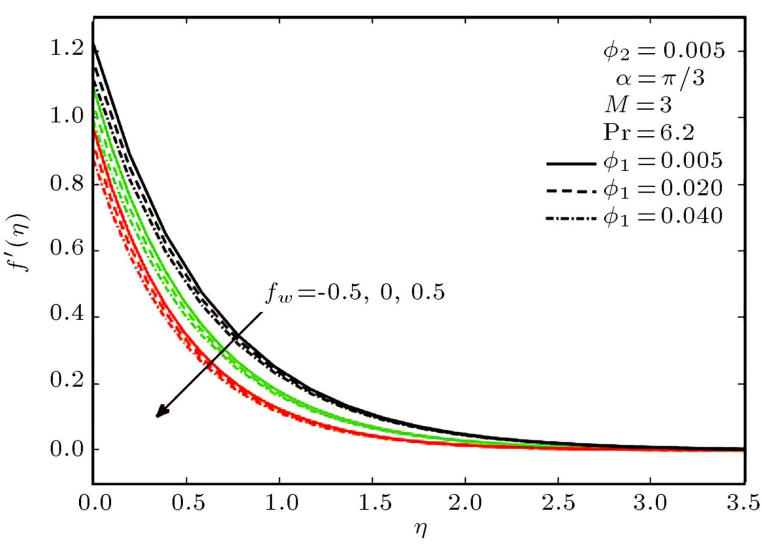

(c) $\mathrm{TiO}_{2}-\mathrm{SiO}_{2} /$ water

Figure 3. Effects of velocity profiles for various values of $\phi_{1}$.

indicates that the overall drags increase. For all of the three hybrid nanofluids, as shown in Figure 5(a), (b), and (c), a notable decrease in the velocity profile has been observed near the wall. Far away from the wall $\mathrm{Al}_{2} \mathrm{O}_{3}-\mathrm{TiO}_{2}$ /water (Figure 5(b)), hybrid nanofluid flow has lower velocity profile than $\mathrm{Al}_{2} \mathrm{O}_{3}-\mathrm{SiO}_{2}$ /water (Figure 5(a)) and $\mathrm{TiO}_{2}-\mathrm{SiO}_{2} /$ water (Figure 5(c)) . This is because the density of $\mathrm{Al}_{2} \mathrm{O}_{3}$ and $\mathrm{TiO}_{2}$ is quite higher than that of $\mathrm{SiO}_{2}$.

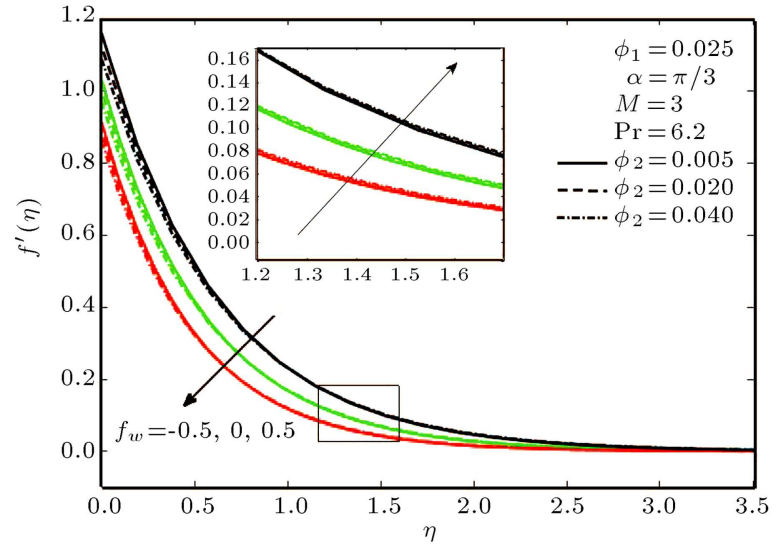

(a) $\mathrm{Al}_{2} \mathrm{O}_{3}-\mathrm{SiO}_{2} /$ water

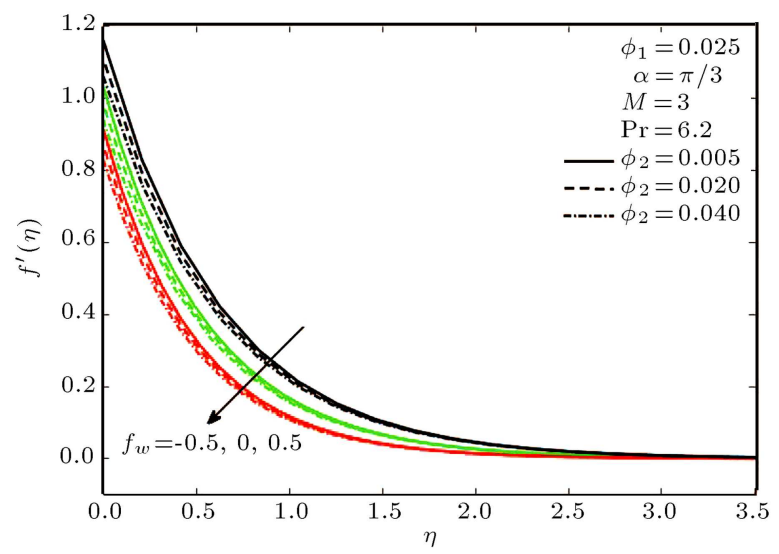

(b) $\mathrm{Al}_{2} \mathrm{O}_{3}-\mathrm{TiO}_{2} /$ water

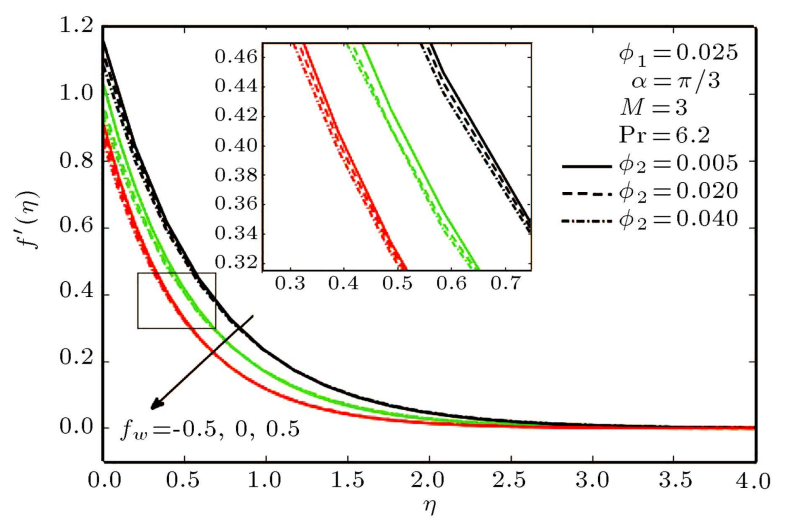

(c) $\mathrm{TiO}_{2}-\mathrm{SiO}_{2} /$ water

Figure 4. Effects of velocity profiles for various values of $\phi_{2}$.

Figure 6 shows the effect of aligned angle $\alpha$ for $\pi / 4$ and $\pi / 2$ with the combined effect of wall mass transfer on the velocity distribution. When $\alpha=\pi / 2$, the aligned magnetic field becomes a transverse magnetic field on the flow area. An increase in the aligned magnetic field parameter is proposed to reduce the velocity of $\mathrm{Al}_{2} \mathrm{O}_{3}-\mathrm{SiO}_{2}$ /water (Figure 6(a)), $\mathrm{Al}_{2} \mathrm{O}_{3}-$ $\mathrm{TiO}_{2}$ /water (Figure 6(b)), and $\mathrm{TiO}_{2}-\mathrm{SiO}_{2} /$ water (Figure 6(c)) hybrid nanofluids in the three cases of suction, impermeability, and injection. The reason behind 


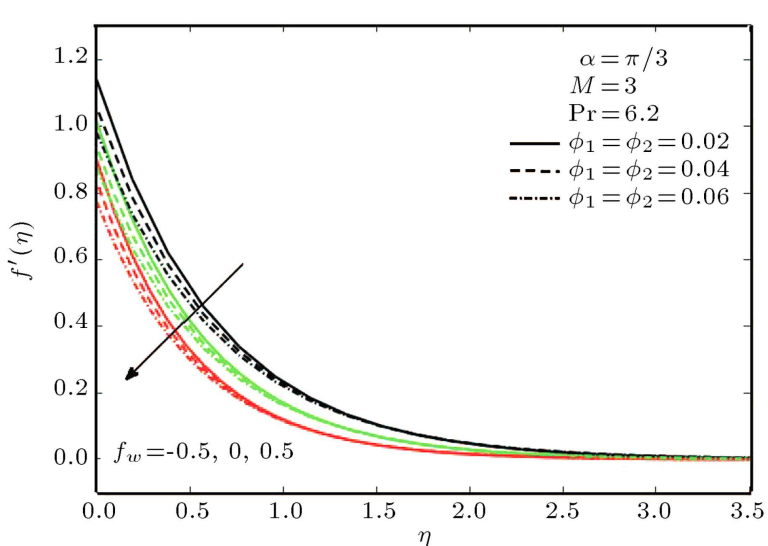

(a) $\mathrm{Al}_{2} \mathrm{O}_{3}-\mathrm{SiO}_{2} /$ water

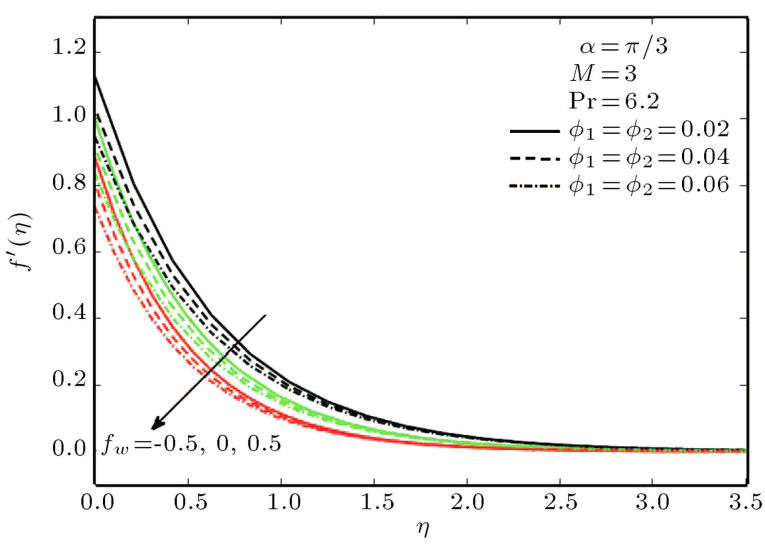

(b) $\mathrm{Al}_{2} \mathrm{O}_{3}-\mathrm{TiO}_{2} /$ water

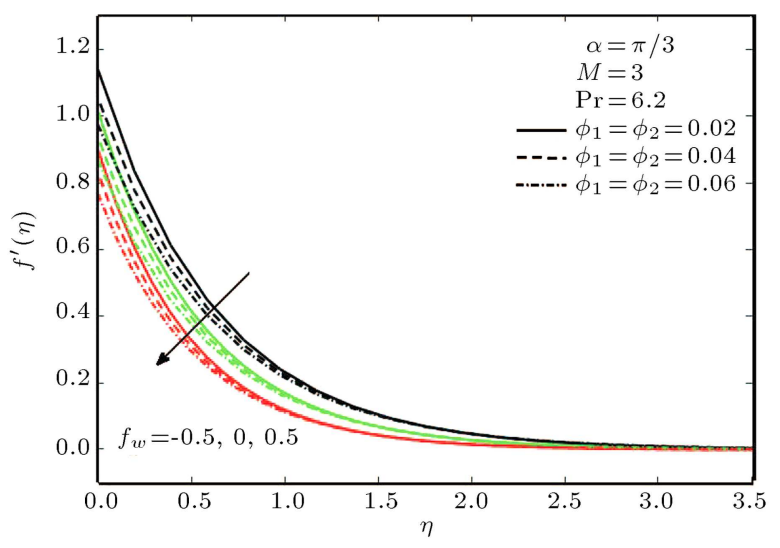

(c) $\mathrm{TiO}_{2}-\mathrm{SiO}_{2} /$ water

Figure 5. Effects of velocity profiles for various values of $\phi_{1}=\phi_{2}$.

this behavior is an increase in the aligned angle that dominates the applied magnetic field, which pledges the Lorentz force in the flow area. This force increases the friction force between the layers, hence depreciating the velocity profile.

Figure 7 illustrates the escalating temperature distribution of hybrid nanofluids with respect to the different solid volume fractions $\phi_{1}$ of $\mathrm{Al}_{2} \mathrm{O}_{3}$ in the hybrid nanofluids of $\mathrm{Al}_{2} \mathrm{O}_{3}-\mathrm{SiO}_{2} /$ water (Figure $7(\mathrm{a})$ )

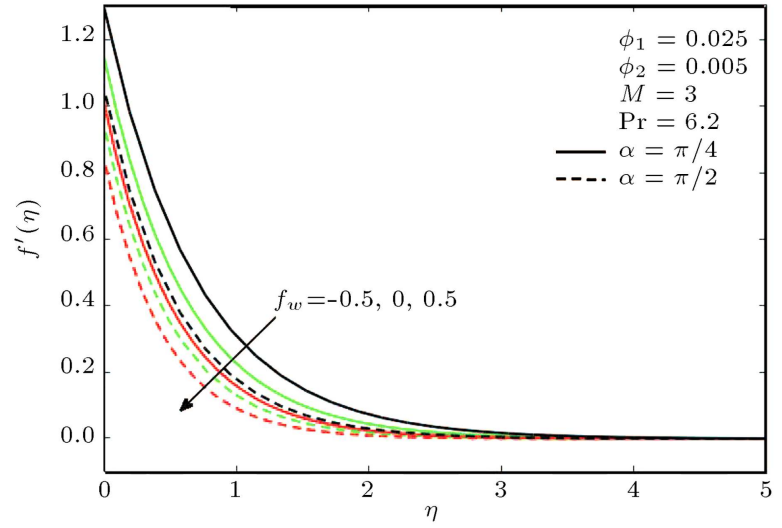

(a) $\mathrm{Al}_{2} \mathrm{O}_{3}-\mathrm{SiO}_{2} /$ water

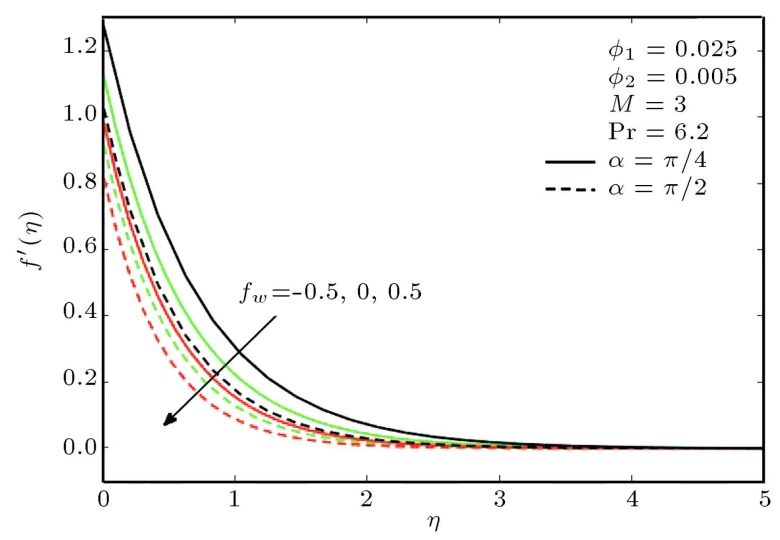

(b) $\mathrm{Al}_{2} \mathrm{O}_{3}-\mathrm{TiO}_{2} /$ water

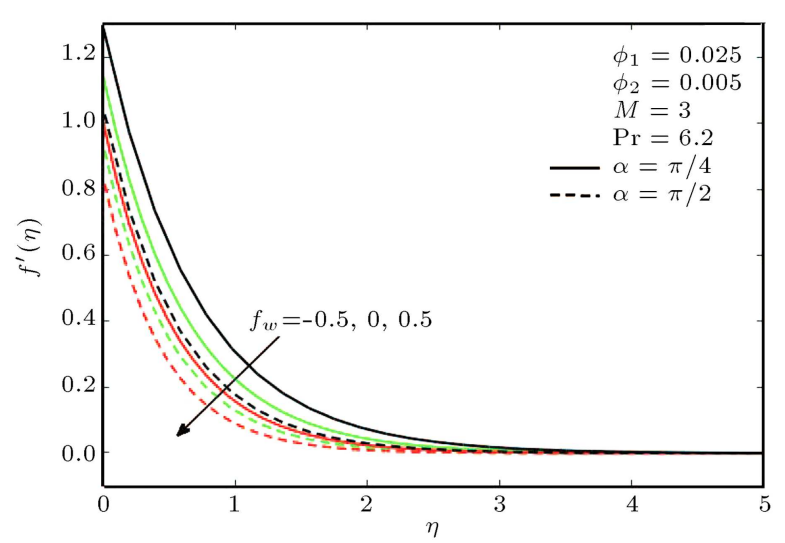

(c) $\mathrm{TiO}_{2}-\mathrm{SiO}_{2} /$ water

Figure 6. Effects of velocity profiles for various values of $\alpha$.

and $\mathrm{Al}_{2} \mathrm{O}_{3}-\mathrm{TiO}_{2}$ /water (Figure $7(\mathrm{~b})$ ) and of $\mathrm{TiO}_{2}$ in the hybrid nanofluid of $\mathrm{TiO}_{2}-\mathrm{SiO}_{2} /$ water (Figure $7(\mathrm{c})$ ). This phenomenon occurs because the hybrid nanoparticles have lower specific heat and greater thermal conductivity parallel to those of the base fluid (water). Hence, all of the three hybrid nanofluids increase the temperature profile. The increase of wall mass transfer $\left(f_{w}\right)$ decreases the temperature distribution. In the case of escalating $f_{w}$, the fluid flows closer to the 


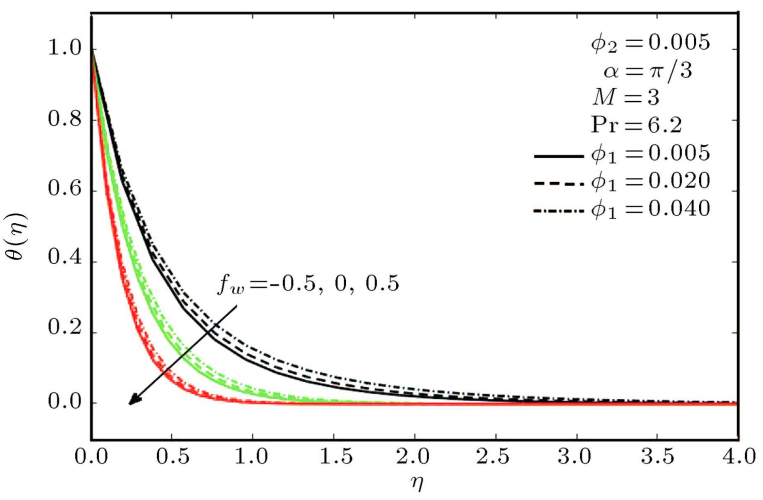

(a) $\mathrm{Al}_{2} \mathrm{O}_{3}-\mathrm{SiO}_{2} /$ water

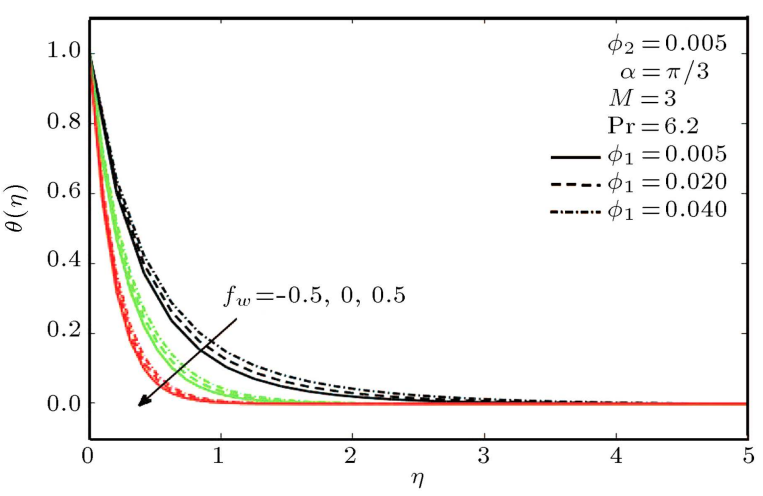

(b) $\mathrm{Al}_{2} \mathrm{O}_{3}-\mathrm{TiO}_{2} /$ water

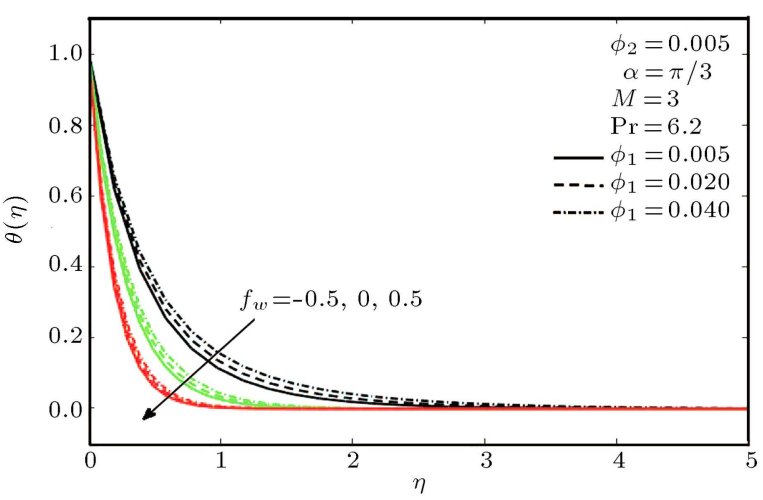

(c) $\mathrm{TiO}_{2}-\mathrm{SiO}_{2} /$ water

Figure 7. Effects of temperature profiles for various values of $\phi_{1}$.

surface and, thus, the thermal boundary layer thickness is reduced.

The effect of the solid volume fraction $\phi_{2}$ on the temperature profiles for $f_{w}=-0.5, f_{w}=0$, and $f_{w}=$ 0.5 is plotted in Figure 8. Figure 8(a) and (c) show an increase in $\phi_{2}$ of $\mathrm{SiO}_{2}$ within $\mathrm{Al}_{2} \mathrm{O}_{3}-\mathrm{SiO}_{2}$ /water and $\mathrm{TiO}_{2}-\mathrm{SiO}_{2} /$ water hybrid nanofluids, respectively, and Figure 8(b) shows $\mathrm{TiO}_{2}$ in $\mathrm{SiO}_{2}-\mathrm{TiO}_{2}$ /water hybrid nanofluid, yielding an increase in the hybrid nanofluid temperature. Based on the comparison made for the increment rates of solid volume fraction $\phi_{2}$, the energy field hike shown in Figure $8(\mathrm{~b})$ is higher than

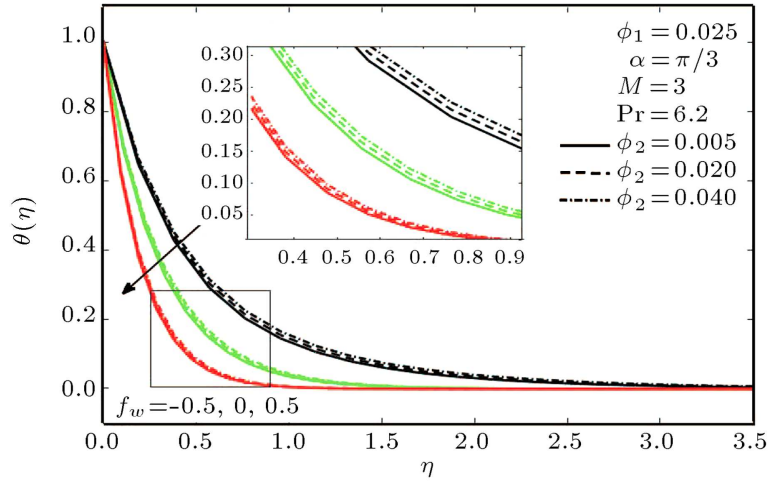

(a) $\mathrm{Al}_{2} \mathrm{O}_{3}-\mathrm{SiO}_{2} /$ water

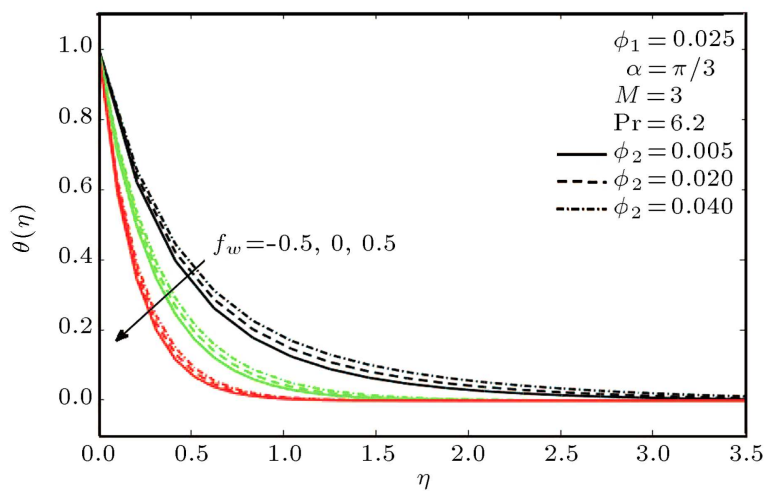

(b) $\mathrm{Al}_{2} \mathrm{O}_{3}-\mathrm{TiO}_{2} /$ water

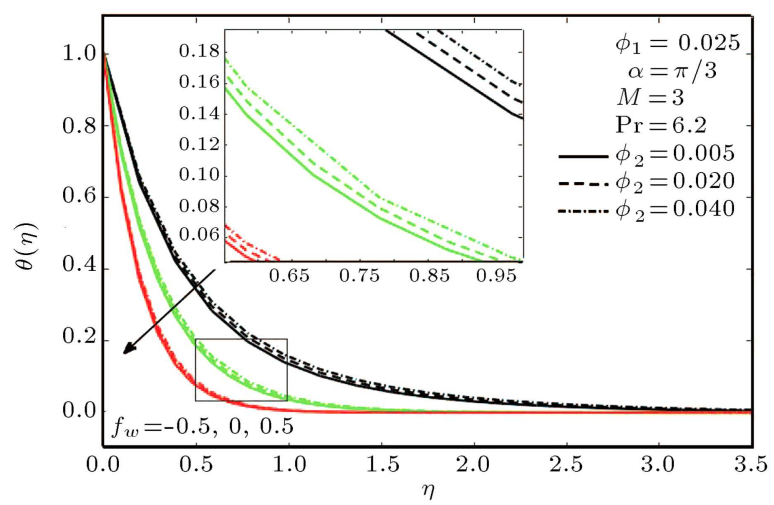

(c) $\mathrm{TiO}_{2}-\mathrm{SiO}_{2} /$ water

Figure 8. Effects of temperature profiles for various values of $\phi_{2}$.

that in Figure 8(a) and (c). This is because the thermal conductivity of $\mathrm{TiO}_{2}$ is more elevated than that of $\mathrm{SiO}_{2}$. The thermal boundary layer turns slenderer for injection $\left(f_{w}=-0.5\right)$ and denser for suction $\left(f_{w}=0.5\right)$, while it remains balanced with the impermeable surface $\left(f_{w}=0\right)$ for all of the three hybrid nanofluids. This result is compatible with the physical consequence.

Figure 9 portrays a variation of equal solid volume fractions when $\phi_{1}=\phi_{2}$ and wall mass transfer $\left(f_{w}\right)$ regarding the temperature field. The temperature profile increases while escalating the values of solid 


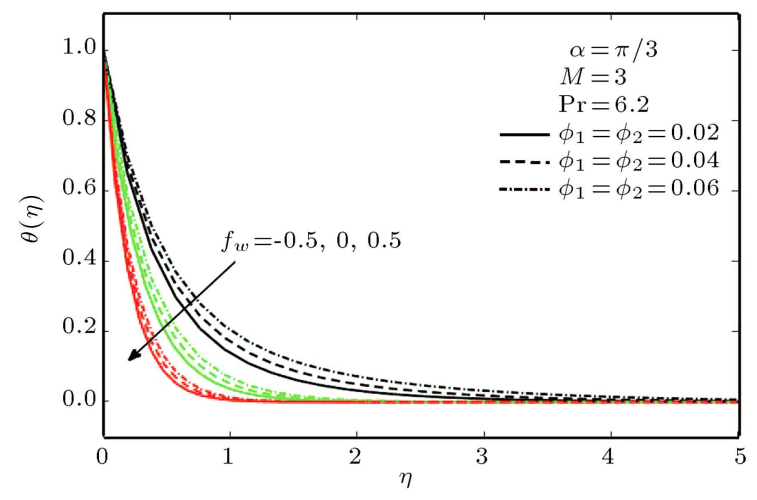

(a) $\mathrm{Al}_{2} \mathrm{O}_{3}-\mathrm{SiO}_{2} /$ water

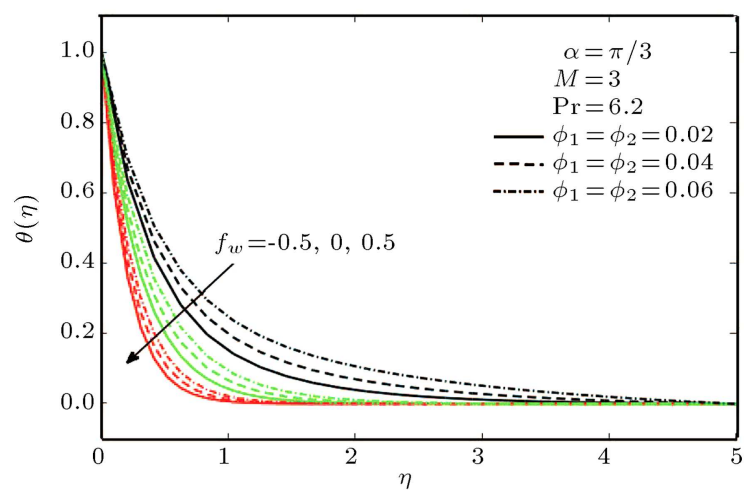

(b) $\mathrm{Al}_{2} \mathrm{O}_{3}-\mathrm{TiO}_{2} /$ water

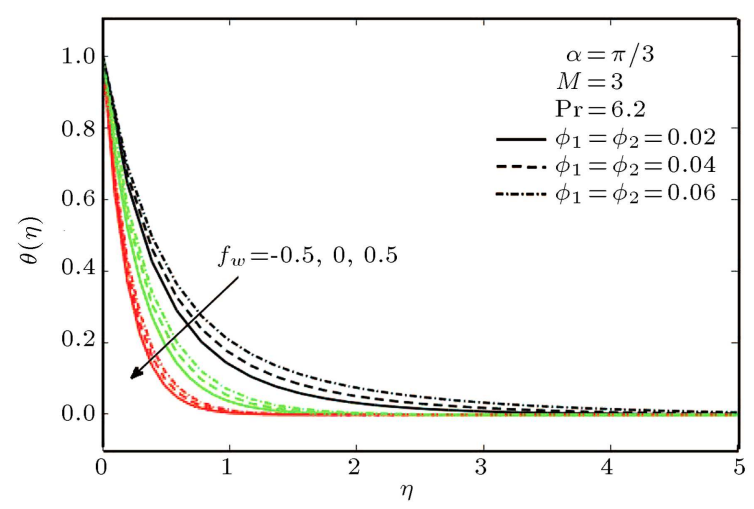

(c) $\mathrm{TiO}_{2}-\mathrm{SiO}_{2} /$ water

Figure 9. Effects of temperature profiles for various values of $\phi_{1}=\phi_{2}$.

volume fraction of both nanoparticles at the same time for the hybrid nanofluids of $\mathrm{Al}_{2} \mathrm{O}_{3}-\mathrm{SiO}_{2}$ /water, $\mathrm{Al}_{2} \mathrm{O}_{3}-$ $\mathrm{TiO}_{2}$ /water, and $\mathrm{TiO}_{2}-\mathrm{SiO}_{2} /$ water in Figure 9(a), (b), and $(\mathrm{c})$, respectively. The temperature distribution increase of $\mathrm{Al}_{2} \mathrm{O}_{3}-\mathrm{SiO}_{2}$ /water (Figure 9(a)) and $\mathrm{TiO}_{2}-$ $\mathrm{SiO}_{2} /$ water (Figure 9(c)) hybrid nanofluids is lower than that of $\mathrm{Al}_{2} \mathrm{O}_{3}-\mathrm{TiO}_{2} /$ water (Figure $9(\mathrm{~b})$ ) hybrid nanofluid. At the same time, while the wall mass transfer $\left(f_{w}\right)$ for the three hybrid nanofluids increases, the temperature profile decreases.

Figure 10(a)-(c) show the temperature distribution deviation of flow at various values of the aligned

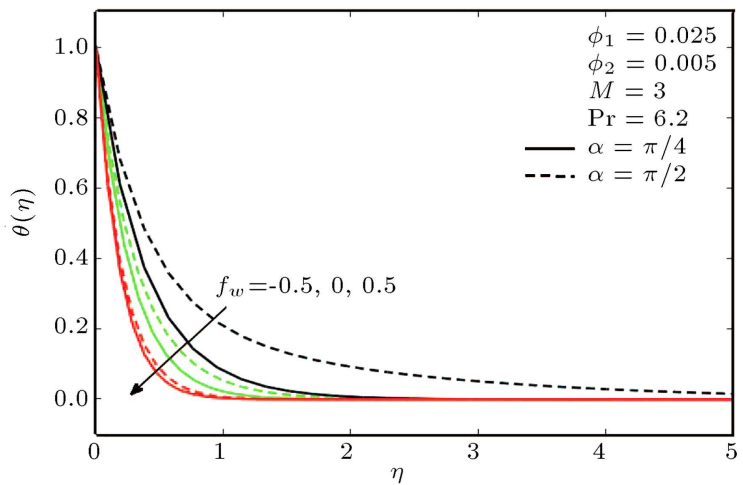

(a) $\mathrm{Al}_{2} \mathrm{O}_{3}-\mathrm{SiO}_{2} /$ water

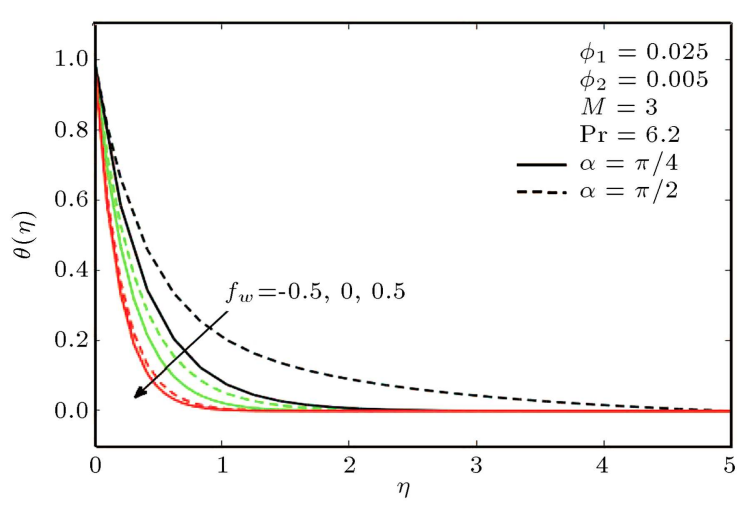

(b) $\mathrm{Al}_{2} \mathrm{O}_{3}-\mathrm{TiO}_{2} /$ water

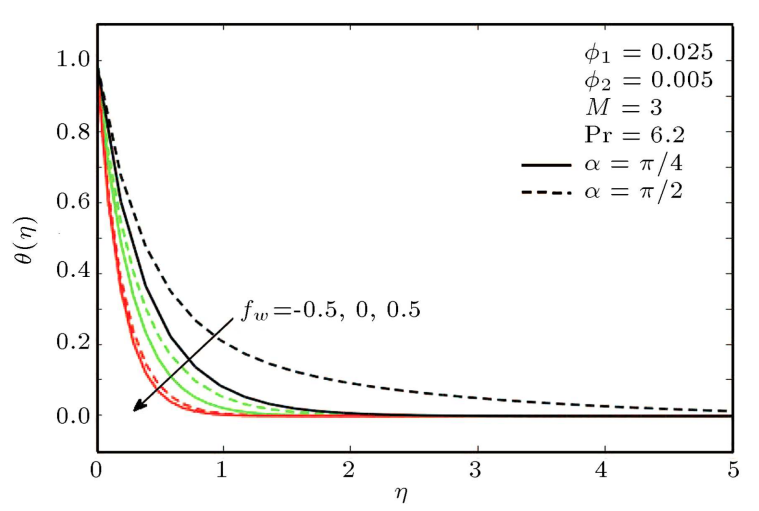

(c) $\mathrm{TiO}_{2}-\mathrm{SiO}_{2} /$ water

Figure 10. Effects of temperature profiles for various values of $\alpha$.

angle parameter and the wall mass transfer parameter for the three hybrid nanofluids. As the aligned angle increases, the external magnetic field hikes, giving rise to the drag force; this has led to the increase of the thermal distribution in the suction, impermeability, and injection cases in a similar manner to $\mathrm{Al}_{2} \mathrm{O}_{3}-$ $\mathrm{SiO}_{2}$ /water (Figure 10(a)), $\mathrm{Al}_{2} \mathrm{O}_{3}-\mathrm{TiO}_{2} /$ water (Figure $10(\mathrm{~b})$ ), and $\mathrm{TiO}_{2}-\mathrm{SiO}_{2}$ / water (Figure 10(c)) hybrid nanofluids. The increasing values of the wall mass transfer parameter $(-0.5,0,0.5)$ reduce the hybrid nanofluid flow. By forcing the liquid out through a permeable flat plate, the temperature decreases due to 
Table 3. The effect of the wall mass transfer $\left(f_{w}\right)$ and magnetic parameter $(M)$ on $f^{\prime}(0)$ for the three hybrid nanofluids when $\operatorname{Pr}=6.2, \alpha=\pi / 3, \phi_{1}=2.5 \%$, and $\phi_{2}=0.5 \%$.

\begin{tabular}{|c|c|c|c|c|}
\hline$f_{w}$ & $M$ & $\mathrm{Al}_{2} \mathrm{O}_{3}-\mathrm{SiO}_{2} /$ water & $\mathrm{Al}_{2} \mathrm{O}_{3}-\mathrm{TiO}_{2} /$ water & $\mathrm{TiO}_{2}-\mathrm{SiO}_{2} /$ water \\
\hline-0.4 & \multirow{8}{*}{3} & 1.15077 & 1.14688 & 1.14875 \\
\hline-0.3 & & 1.12434 & 1.12039 & 1.12229 \\
\hline-0.2 & & 1.09818 & 1.09419 & 1.09611 \\
\hline-0.1 & & 1.07233 & 1.06829 & 1.07024 \\
\hline 0.1 & & 1.02163 & 1.01750 & 1.01949 \\
\hline 0.2 & & 0.99682 & 0.99266 & 0.99467 \\
\hline 0.3 & & 0.97242 & 0.96822 & 0.97024 \\
\hline 0.4 & & 0.94843 & 0.94420 & 0.94624 \\
\hline \multirow{5}{*}{-0.5} & 1 & 1.48516 & 1.48109 & 1.48307 \\
\hline & 2 & 1.31161 & 1.30764 & 1.30955 \\
\hline & 3 & 1.17746 & 1.17362 & 1.17547 \\
\hline & 4 & 1.07183 & 1.06815 & 1.06992 \\
\hline & 5 & 0.98696 & 0.98343 & 0.98513 \\
\hline \multirow{5}{*}{0} & 1 & 1.30877 & 1.30424 & 1.30644 \\
\hline & 2 & 1.16009 & 1.15578 & 1.15786 \\
\hline & 3 & 1.04680 & 1.04272 & 1.04469 \\
\hline & 4 & 0.95814 & 0.95427 & 0.95614 \\
\hline & 5 & 0.88697 & 0.88331 & 0.88507 \\
\hline \multirow{5}{*}{0.5} & 1 & 1.13856 & 1.13365 & 1.13603 \\
\hline & 2 & 1.01698 & 1.01241 & 1.01461 \\
\hline & 3 & 0.92488 & 0.92062 & 0.92267 \\
\hline & 4 & 0.85272 & 0.84874 & 0.85066 \\
\hline & 5 & 0.79454 & 0.79079 & 0.79260 \\
\hline
\end{tabular}

an increase in the wall mass transfer, which is shown in Figure 10.

Table 3 illustrates the effect of surface velocity in the case of the suction, injection, and impermeability under parameter $f_{w}$ and magnetic parameter $M$, where other parameters including Prandtl number, aligned angle, and solid volume fraction of hybrid nanoparticles remain constant. According to Table $3, f^{\prime}(0)$ decreases for both $f_{w}$ and $M$. Among the three hybrid nanofluids, $\mathrm{Al}_{2} \mathrm{O}_{3}-\mathrm{TiO}_{2} /$ water and $\mathrm{Al}_{2} \mathrm{O}_{3}-\mathrm{SiO}_{2}$ /water hybrid nanofluids have lower and higher surface velocities than $\mathrm{TiO}_{2}-\mathrm{SiO}_{2} /$ water hybrid nanofluid, respectively. Table 4 gives a numerical calculation to investigate the effect of Nusselt number. It is clear from Table 4 that with the increasing values of the wall mass transfer parameter while keeping other physical parameters constant, the Nusselt number increases for the three hybrid nanofluids. However, given the increasing values of the magnetic parameter and considering other parameters constant, the heat transfer rate decreases for all of the three distinct hybrid nanofluids in the suction, impermeability, and injection cases of wall mass transfer parameter. However, the $\mathrm{TiO}_{2}-\mathrm{SiO}_{2}$ / water hybrid nanofluid has a higher heat transfer rate and $\mathrm{Al}_{2} \mathrm{O}_{3}-$ $\mathrm{TiO}_{2}$ /water hybrid nanofluid has a lower heat transfer rate than $\mathrm{Al}_{2} \mathrm{O}_{3}-\mathrm{SiO}_{2}$ /water hybrid nanofluid.

\section{Conclusion}

The current study investigated the three individual hybrid nanofluids past a permeable flat surface in the cases of suction, injection, and impermeability with the aligned magnetic field and Marangoni convection. The numerical results corresponding to the solid volume fraction of both nanoparticles, aligned angle, and wall mass transfer parameter for aluminium oxidesilicon dioxide/water hybrid nanofluid, aluminium oxide-titanium dioxide/water hybrid nanofluid, and titanium dioxide-silicon dioxide/water hybrid nanofluid were given. The following conclusions are derived from 
Table 4. The effect of the wall mass transfer $\left(f_{w}\right)$ and magnetic parameter $(M)$ on $-\theta^{\prime}(0)$ for the three hybrid nanofluids when $\operatorname{Pr}=6.2, \alpha=\pi / 3, \phi_{1}=2.5 \%$, and $\phi_{2}=0.5 \%$.

\begin{tabular}{|c|c|c|c|c|}
\hline$f_{w}$ & $M$ & $\mathrm{Al}_{2} \mathrm{O}_{3}-\mathrm{SiO}_{2} /$ water & $\mathrm{Al}_{2} \mathrm{O}_{3}-\mathrm{TiO}_{2} /$ water & $\mathrm{TiO}_{2}-\mathrm{SiO}_{2} /$ water \\
\hline-0.4 & \multirow{8}{*}{3} & 2.58029 & 2.56468 & 2.58640 \\
\hline-0.3 & & 2.76010 & 2.74274 & 2.76768 \\
\hline-0.2 & & 2.96308 & 2.94387 & 2.97248 \\
\hline-0.1 & & 3.19044 & 3.16924 & 3.20199 \\
\hline 0.1 & & 3.72017 & 3.69456 & 3.73725 \\
\hline 0.2 & & 3.02206 & 3.99402 & 4.04244 \\
\hline 0.3 & & 4.34748 & 4.31687 & 4.37149 \\
\hline 0.4 & & 4.69513 & 4.66184 & 4.72308 \\
\hline \multirow{5}{*}{-0.5} & 1 & 2.98633 & 2.97158 & 2.99353 \\
\hline & 2 & 2.67895 & 2.66459 & 2.68485 \\
\hline & 3 & 2.42191 & 2.40785 & 2.42684 \\
\hline & 4 & 2.20443 & 2.19081 & 2.20867 \\
\hline & 5 & 2.01821 & 2.00542 & 2.02209 \\
\hline \multirow{5}{*}{0} & 1 & 4.00014 & 3.97591 & 4.01685 \\
\hline & 2 & 3.69601 & 3.67228 & 3.71127 \\
\hline & 3 & 3.44278 & 3.41946 & 3.45692 \\
\hline & 4 & 3.22799 & 3.20503 & 3.24123 \\
\hline & 5 & 3.04248 & 3.01983 & 3.05497 \\
\hline \multirow{5}{*}{0.5} & 1 & 5.50613 & 5.46877 & 5.53972 \\
\hline & 2 & 5.26107 & 5.22438 & 5.29383 \\
\hline & 3 & 5.06351 & 5.02743 & 5.09568 \\
\hline & 4 & 4.90050 & 4.86497 & 4.93224 \\
\hline & 5 & 4.76325 & 4.72823 & 4.79466 \\
\hline
\end{tabular}

the present exploration of the physical parameters for the velocity, energy field, and heat transfer rate:

- The effect of solid volume fraction decelerated the velocity distribution for all of the three hybrid nanofluids in the cases of suction, impermeability, and injection;

- An increase in the aligned angle depreciated the velocity profile in the cases of suction, impermeability, and injection for $\mathrm{Al}_{2} \mathrm{O}_{3}-\mathrm{SiO}_{2}$ / water, $\mathrm{Al}_{2} \mathrm{O}_{3}-$ $\mathrm{TiO}_{2} /$ water, and $\mathrm{TiO}_{2}-\mathrm{SiO}_{2} /$ water hybrid nanofluids;

- For the increment of wall mass transfer parameter, the velocity distribution and energy field declined for aluminium oxide-silicon dioxide/water, aluminium oxide-titanium dioxide/water, and titanium dioxidesilicon dioxide/water hybrid nanofluids;

- The temperature raised with the increment of solid volume fraction for all of the hybrid nanofluids;
- For all of the three hybrid nanofluids, the increasing values of aligned angle increased temperature distribution;

- The rate of heat transfer increased for the hybrid nanofluids $\left(\mathrm{Al}_{2} \mathrm{O}_{3}-\mathrm{SiO}_{2} /\right.$ water, $\mathrm{Al}_{2} \mathrm{O}_{3}-\mathrm{TiO}_{2} /$ water, and $\mathrm{TiO}_{2}-\mathrm{SiO}_{2} /$ water) with the increment of wall mass transfer;

- Among the three hybrid nanofluids: (a) The $\mathrm{Al}_{2} \mathrm{O}_{3}-$ $\mathrm{SiO}_{2} /$ water hybrid nanofluid showed a higher surface velocity, (b) $\mathrm{Al}_{2} \mathrm{O}_{3}-\mathrm{TiO}_{2} /$ water hybrid nanofluid had higher temperature profile, and (c) $\mathrm{TiO}_{2}-\mathrm{SiO}_{2} /$ water hybrid nanofluid exhibited a higher heat transfer rate.

\section{Nomenclature}

$\begin{array}{ll}A & \text { Constant } \\ B_{0} & \text { Uniform magnetic field, T } \\ C_{P} & \text { Specific heat, J.kg.K }{ }^{-1}\end{array}$


$f_{w} \quad$ Wall mass transfer

$k \quad$ Thermal conductivity W. $\mathrm{m}^{-1} \cdot \mathrm{K}^{-1}$

L Surface length, m

$M \quad$ Magnetic parameter, $M=\frac{\delta B_{0}^{2} \sin ^{2} \alpha}{\zeta_{1} \zeta_{2} \rho_{f}}$

$\mathrm{Ma}_{L} \quad$ Marangoni number, $\mathrm{Ma}_{L}=\frac{\sigma_{*} \Delta T L}{\mu_{f} \alpha_{f}}$

$\mathrm{Nu}_{x} \quad$ Local Nusselt number, $\mathrm{Nu}_{x}=$ $-\frac{k_{h n f}}{k_{f}} \zeta_{1} x \theta^{\prime}(0)$

$\mathrm{Nu}_{L} \quad$ Average Nusselt number, $\mathrm{Nu}_{L}=$ $-\frac{k_{h n f}}{k_{f}} \mathrm{Ma}_{L}^{1 / 3} \operatorname{Pr}^{1 / 3} \theta^{\prime}(0)$

$\operatorname{Pr} \quad$ Prandtl number, $\operatorname{Pr}=\frac{\mu_{f} C_{P_{f}}}{k_{f}}$

Re Reynolds number, $\operatorname{Re}=\frac{u_{w} x}{\nu_{f}}$

$T \quad$ Temperature, $\mathrm{K}$

$\Delta T \quad$ Characteristic temperature, $\mathrm{K}$

$x, y \quad$ Cartesian co-ordinate, $\mathrm{m}$

$u, v \quad$ Velocity components along, m.s ${ }^{-1}$

$u_{w}, v_{w} \quad$ Surface velocity, m.s ${ }^{-1}$

Greek symbols

$\alpha \quad$ Aligned angle

$\sigma$

Surface tension, N.m ${ }^{-1}$

$\zeta_{1}, \zeta_{2} \quad$ Constants

$\phi_{1} \quad$ Solid volume fraction of the first nanoparticle of hybrid nanofluid

$\phi_{2} \quad$ Solid volume fraction of the second nanoparticle of hybrid nanofluid

$\nu \quad$ Kinematic viscosity, $\mathrm{m}^{2} \cdot \mathrm{s}^{-1}$

$\gamma \quad$ Positive fluid property

$\mu \quad$ Effective viscosity, N.s.m ${ }^{-2}$

$\rho \quad$ Effective density, $\mathrm{kg} \cdot \mathrm{m}^{-3}$

$\delta \quad$ Electrical conductivity, $\mathrm{S} . \mathrm{m}^{-1}$

\section{Subscripts}

$f \quad$ Fluid

$n f \quad$ Nanofluid

hnf Hybrid nanofluid

* Slit $\quad$ Slit

$s 1 \quad$ First solid nanoparticle of hybrid nanofluid

$s 2 \quad$ Second solid nanoparticle of hybrid nanofluid

$w \quad$ Wall

$\infty \quad$ Far away from the surface

\section{References}

1. Choi, S.U.S. "Enhancing thermal conductivity of fluids with nanoparticle", The Proceedings of the 1995
ASME International Mechanical Engineering Congress and Exposition, San Francisco, USA, ASME, FED 231/MD66, pp. 99-105 (1995).

2. Afrand, M., Nazari Najafabadi, K., and Akbari, M. "Effects of temperature and solid volume fraction on viscosity of $\mathrm{SiO}_{2}-\mathrm{MWCNTs} / \mathrm{SAE} 40$ hybrid nanofluid as a coolant and lubricant in heat engines", Appl. Therm. Eng., 102, pp. 45-54 (2016).

3. Kamble, D.P., Gadhave, P.S., and Anwar, M.A. "Enhancement of thermal performance of heat pipe using hybrid nanofluid", International Journal of Engineering Trends and Technology, 17, pp. 425-428 (2014).

4. Syam Sundar, L., Sousa, A.C.M., and Singh, M.K. "Heat transfer enhancement of low volume concentration of carbon nanotube- $\mathrm{Fe}_{3} \mathrm{O}_{4} /$ Water hybrid nanofluids in a tube with twisted tape inserts under turbulent flow", J. Therm. Sci. Eng. Appl., 7, 021015 (2015).

5. Sidik, N.A.C., Mohammed, H.A., Alawi, O.A., and Samion, S. "A review on preparation methods and challenges of nanofluids", International Communications in Heat and Mass Transfer, 54, pp. 115-125 (2014).

6. Sarkar, J., Ghosh, P., and Adil, A. "A review on hybrid nanofluids: Recent research, development and applications", Renewable and Sustainable Energy Reviews, 43, pp. 164-177 (2015).

7. Momin, G.G. "Experimental investigation of mixed convection with water- $\mathrm{Al}_{2} \mathrm{O}_{3}$ and hybrid nanofluid in inclined tube for laminar flow", International Journal of Scientific and Technology Research, 2(12), pp. 195202 (2013).

8. Moldoveanu, G.M., Minea, A.A., Iacob, M., Ibanescu, C., and Danu, M. "Experimental study on viscosity of stabilized $\mathrm{Al}_{2} \mathrm{O}_{3}, \mathrm{TiO}_{2}$ nanofluids and their hybrid", Thermochimica Acta, 659, pp. 203-212 (2018).

9. Moldoveanu, G.M., Ibanescu, C., Danu, M., and Minea, A.A. "Viscosity estimation of $\mathrm{Al}_{2} \mathrm{O}_{3}, \mathrm{SiO}_{2}$ nanofluids and their hybrid: An experimental study", J. Mol. Liq., 253, pp. 188-196 (2018).

https://doi.org/10.1016/j.molliq.2018.01. 061.

10. Abdul Hamid, K., Azmi, W.H., Nabil, M.F., Razalman, M., and Sharma, K.V. "Experimental investigation of thermal conductivity and dynamic viscosity on nanoparticle mixture ratios of $\mathrm{TiO}_{2}-\mathrm{SiO}_{2}$ nanofluids", Int. J. Heat Mass Transf., 116, pp. 1143-1152 (2018).

11. Sahoo, R.R., Ghosh, P., and Sarkar, J. "Performance analysis of a louvered fin automotive radiator using hybrid nanofluid as coolant", Heat Tran. Asian Res., 46(7), pp. 978-995 (2017).

12. Anjali Devi, S.P. and Suriya Uma Devi, S. "Numerical investigation of hydromagnetic hybrid $\mathrm{Cu}$ $\mathrm{Al}_{2} \mathrm{O}_{3}$ /water nanofluid flow over a permeable stretching sheet with suction", Int. J. of Nonlin. Sci. Num., 17(5), pp. 249-257 (2016). 
13. Hayat, T. and Nadeem, S. "Heat transfer enhancement with $\mathrm{Ag}-\mathrm{CuO} /$ water hybrid nanofluid", Results in Physics, 7, pp. 2317-2324 (2017).

14. Azwadi, C.S.N., Adamu, I.M., and Jamil, M.M. "Preparation methods and thermal performance of hybrid nanofluids", Journal Advanced Review on Scientific Research, 24(1), pp. 13-23 (2016).

15. Gorla, R.S.R., Mansour, M.A., Rashad, A.M., and Salah, T. "Heat source/sink effects on a hybrid nanofluid-filled porous cavity", J. Thermophys. Heat Tr., 31(4), pp. 1-11 (2017). https://doi. org $/ 10.2514 / 1$.T5085

16. Kuznetsov, A.V. and Nield, D.A. "Natural convective boundary-layer flow of a nanofluid past a vertical plate", Int. J. Therm. Sci., 49, pp. 243-247 (2010).

17. Wakif, A., Boulahia, Z., Ali, F., Eid, M., and Sehaqui, R. "Numerical analysis of the unsteady natural convection MHD Couette nanofluid flow in the presence of thermal radiation using single and two-phase nanofluid models for Cu-water nanofluids", International Journal of Applied and Computational Mathematics, 4, p. 81 (2018).

18. Sheikholeslami, M., Hayat, T., and Alsaedi, A. "MHD free convection of $\mathrm{Al}_{2} \mathrm{O}_{3}$ water nanofluid considering thermal radiation: A numerical study", Int. J. Heat Mass Transf., 96, pp. 513-524 (2016).

19. Abdul Hakeem, A.K., Vishnu Ganesh, N., and Ganga, B. "Magnetic field effect on second order slip flow of nanofluid over a stretching/shrinking sheet with thermal radiation effect", J. Magn. Magn. Mater., 381, pp. 243-257 (2015).

20. Hussain, S.M., Jain, J., Seth, G.S., and Rashidi, M.M. "Effect of thermal radiation on magneto-nanofluids free convective flow over an accelerated moving ramped temperature plate", Scientia Iranica, B, 25(3), pp. 1243-1257 (2018).

21. Abdul Hakeem, A.K., Vishnu Ganesh, N., and Ganga, B. "Heat transfer of non-Darcy MHD flow of nanofluid over a stretching/shrinking surface in a thermally stratified medium with second order slip model", Scientia Iranica, F, 22(6), pp. 2766-2784 (2015).

22. Eswaramoorthi, S., Bhuvaneswari, M., Sivasankaran, S., and Rajan, S. "Soret and Dufour effects on viscoelastic boundary layer flow over a stretching surface with convective boundary condition with radiation and chemical reaction", Scientia Iranica, B, 23(6), pp. $2575-2586$ (2016).

23. Eid, M.R. "Chemical reaction effect on MHD boundary-layer flow of two-phase nanofluid model over an exponentially stretching sheet with a heat generation", J. Mol. Liq., 220, pp. 718-725 (2016).

24. Qayyum, S., Hayat, T., and Alsaedi, A. "Thermal radiation and heat generation/absorption aspects in third grade magneto-nanofluid over a slendering stretching sheet with Newtonian conditions", Physica B:, 537(15), pp. 139-149 (2018).
25. Ganga, B., Mohamed Yusuff Ansari, S., Vishnu Ganesh, N., and Abdul Hakeem, A.K. "MHD radiative boundary layer flow of nanofluid past a vertical plate with internal heat generation/absorption, viscous and ohmic dissipation effects", J. Nigerian Math., 34(2), pp. 181-194 (2015).

26. Eid, M.R. and Mahny, K.L. "Unsteady MHD heat and mass transfer of a non-Newtonian nanofluid flow of a two-phase model over a permeable stretching wall with heat generation/absorption", Advanced Powder Technology, 28(11), pp. 3063-3073 (2017).

27. Abdul Hakeem, A.K., Govindaraju, M., Ganga, B., and Kayalvizhi, M. "Second law analysis for radiative MHD slip flow of a nanofluid over a stretching sheet with non-uniform heat source effect", Scientia Iranica, F, 23(3), pp. 1524-1538 (2016).

28. Eid, M.R. and Makinde, O.D. "Solar radiation effect on a magneto nanofluid flow in a porous medium with chemically reactive species", Int. J. Chem. React. Eng., 16(9), 20170212 (2018). https://doi.org/10.1515/ijcre-2017-0212

29. Hayat, T., Farooq, S., and Ahmad, B. "The impact of compliant walls on magneto hydrodynamics peristalsis of Jeffrey material in a curved configuration", Scientia Iranica, B, 25(2), pp. 741-750 (2018).

30. Al-Mudhaf, A. and Chamkha, A.J. "Similarity solutions for MHD thermosolutal Marangoni convection over a flat surface in the presence of heat generation or absorption effects", Heat Mass Transfer, 42, pp. 112121 (2005).

31. Hayat, T., Shaheen, U., Shafiq, A., Alsaedi, A. and Asghar, S. "Marangoni mixed convection flow with Joule heating and nonlinear radiation", AIP Advances, 5, 077140 (2015).

32. Christopher, D.M. and Wang, B. "Prandtl number effects for Marangoni convection over a flat surface", Int. J. Therm. Sci., 40, pp. 564-570 (2001).

33. Chamkha, A.J., Pop, I., and Takhar, H.S. "Marangoni mixed convection boundary layer flow", Meccanica, 41, pp. 219-232 (2006).

34. Sastry, D.R.V.S.R.K., Murti, A.S.N., and Poorna Kantha, T. "The effect of heat transfer on MHD Marangoni boundary layer flow past a flat plate in nanofluid", International Journal of Engineering Mathematics, 581507,6 pages (2013).

35. Arifin, N.M., Nazar, R., and Pop, I. "Marangonidriven boundary layer flow in nanofluids", Proceedings of the 2010 International Conference on Theoretical and Applied Mechanics 2010 and 2010 International Conference on Fluid Mechanics and Heat and Mass Transfer, pp. 32-35 (2010).

36. Abdul Hamid, R. and Arifin, N.M. "The effect of wall suction/injection on MHD Marangoni convection boundary layer flow in nanofluid", Proceedings of 21st National Symposium on Mathematical Sciences(SKSM21) AIP Conference Proceedings, 1605, pp. 386-391 (2014). 


\section{Biographies}

Abdul Kaffoor Abdul Hakeem was born and brought up in the district of Coimbatore, Tamil Nadu, India. He obtained MSc and MPhil degrees in Mathematics from Bharathiar University, Coimbatore. He was awarded PhD degree in Fluid Dynamics by Bharathiar University in 2008. He has been working as an Assistant Professor at the Department of Mathematics, the Sri Ramakrishna Mission Vidhyalaya College of Arts and Science, Coimbatore Affiliated to Bharathiar University, as an Assistant Professor since 2008. Besides teaching, he is actively engaged in research in the field of Fluid Mechanics, particularly in heat transfer in cavities, boundary layer flows, nanofluid flow through porous media, second-grade fluid flow, and slip flow model.

Nandakumar Indumathi is a research scholar at the Department of Mathematics in Sri Ramakrishna Mission Vidyalaya College of Arts and Science, Coimbatore, Tamil Nadu, India. She is currently doing her $\mathrm{PhD}$ under the guidance of Dr. Abdul Hakeem.

Bhose Ganga was born and brought up in the district of the Nilgiri's, Tamil Nadu, India. She obtained MPhil and $\mathrm{PhD}$ degrees in Mathematics from Bharathiar
University, Coimbatore. She has been working as an Assistant Professor at the Department of Mathematics, Providence College for Women, Coonoor, Affiliated to Bharathiar University since 2007. Besides teaching, she is actively engaged in research in the field of Fluid mechanics particularly in boundary layer flows, nanofluid flow through porous media, and slip flow model.

Manoj Kumar Nayak is presently working as a faculty member of Physics, IHSE, Siksha 'O' Anusandhan Deemed to be University, Bhubaneswar, India. Earlier, Dr. Nayak was an Associate Professor and HOD, Department of Physics, Radhakrishna Institute of Technology and Engineering, Biju Patnaik University of Technology, Odisha, India. He has about 23 years of teaching and research experience in area of applied physics, fluid dynamics, material science and engineering, heat and mass transfer, nanofluid, magnetohydrodynamics, and non-linear analysis. He has about 46 research papers in SCI and Scopus referred journals. He has authored 10 books for graduate and undergraduate students. He is currently an editorial board member of Electronics Science Technology and Application and Frontiers in Mechatronic Engineering. He is a reviewer of many international SCI and Scopus journals. He is a life member of ISTE, New Delhi, India and IAAM, Sweden. 